\title{
FACTORS INFLUENCING EMPLOYMENT AND UNEMPLOYMENT POLICIES IN BULGARIA
}

\author{
Venelin Terziev \\ Academician of the Russian Academy of Natural History, Moscow, Russia, \\ Prof. D.Sc. (Ec.), D.Sc. (National Security), D.Sc. (Social Activities), Ph.D., National Military \\ University, Veliko Tarnovo, Bulgaria; University of Rousse, Rousse, Bulgaria, terziev@skmat.com

\begin{abstract}
The adequacy and timeliness of an implemented policy are crucial for the effective support of changes in the parameters of the labour market and economic development. Considering the time delay of the effects and changes. its duration should not be overlooked in order to develop preventive measures for a timely response. Shortening the period in which the effects of the contemporary crisis are transferred on the labour market, respectively labour demand, reflects not only the degree of elasticity of labour demand to primary markets, but also the flexibility of the implemented policies. This fact has focused attention on the flexibility of labour markets and opportunities through its increase to strengthen the mobility and adaptability of the workforce to the dynamically evolving labour demand.
\end{abstract}

Keywords: labour market, employment, unemployment, social policies.

\section{INTRODUCTION}

Based on the presented processes of labour market development and the policies implemented we can make a number of conclusions about the economic activity, employment and unemployment.

Economic activity, the population's employment in production jobs, is the most important factor for the economic growth and success of the integration processes. Employment as a factor of economic growth is important for Bulgaria with its quality structures, sectoral redeployment, mobility and price. Employ-ment, as a level and structure, is the result of the economic development of the radical changes occurring in the structure of ownership and production. To a large extent, however, it is the result of the ongoing economic, social and politi-cal reforms.

The decline in the 1990s in the economic activity of the population, and even more in its employment, the high and persistent unemployment, and the mass impoverishment resulted in the contraction of the domestic market and op-portunities for developing the production and increasing the employment. All this reduced social security (even if only in terms of social security funds) and slowed the development of society, making the transition to a market economy prolonged and at high social and economic costs.

The restructuring of the workforce and changes in the employment of the population in Bulgaria are radical, large-scale and diverse. Broadly they are di-vided into two large groups: those towards building a market economy in the country, expanding the opportunities for the country's accession to the EU; and the others, 
creating difficulties, barriers to the successful accession and devel-opment en-route to a market economy and democracy. The latter require an ade-quate policy for increasing employment and reducing unemployment in the con-text of the policies, strategies and plans agreed upon by the EU Member States (Georgiev, 2016; Georgiev, 2017-a).

\section{FACTORS INFLUENCING EMPLOYMENT AND UNEMPLOYMENT POLICIES}

The first group of changes in employment, creating a good basis and opportunities for our country's integration into the EU and its development towards a market economy and democracy includes the following:

- A change in the employment model - from administrative to market allocation of employees and their mobility; from full employment on a social basis to unemployment and uncertainty about the paid labour; from passive to active behaviour and competition in the labour market;

- Elimination of the administrative restrictions in the movement of labour within and outside the country, creation of conditions, though yet limited, for larger labour mobility;

- A shift from administrative to contractual relations in the sphere of paid employment, negotiating the price of labour and the other conditions of employment between the direct participants in the labour process (employees and employers);

- Creating a new and radical change in the labour and social legislation existing in the country in the context of the development of the market economy and the democratic processes, and in line with the international conventions, European directives, etc.;

- Building and developing social partnership at all levels and developing the system of collective bargaining;

- Creating and developing in the labour market and its institutions and policies by building the network of employment services throughout the country, equipping them and qualifying the people employed in them;

- Creating and developing a policy to regulate the labour market, an active policy to stimulate the unemployed to return to work and employers to hire certain groups of unemployed;

- Restructuring the sectoral employment, increasing rapidly the number of employees in services and reducing the number of employees in industry;

- Increasing the number of private sector employees, entrepreneurs and self- employed;

- Developing the forms of employment, albeit still limitedly at this stage and slowly increasing the number of part-time employees, etc.;

- A rapid increase in the number of people employed in non-governmental organizations as a kind of guarantee for the development of the civil society in the country.

The following can be attributed to the second group of changes in employment that create problems and barriers to the economic growth and social cohesion:

The participation of the population in the sphere of paid labour, employment and economic development is decreasing. The economic burden of workers (social contributions, taxes, restrictions on wage growth, etc.) is increasing. The drastic reduction in the employment of young people, ethnic groups, women and rural population stands out in the general decline in employment. As a result, there is a growing number of poor and impoverished, of people excluded from the world of work. The number of the economically active population dependent on and in need of social benefits is high. A part of the unemployed (mainly long-term unemployed) find it difficult to return to work, for another part it has become impossible to provide education to their children. The drop-outs for that reason are numerous.

Despite the significant contraction in employment in the 1990s (around 40\% compared to 1989), the hidden unemployment and inefficient use of employees remain high. Increasing the efficiency and the competitiveness of much of national production requires reducing the share of the costs of production, including labour costs. This virtually requires dismissal of some of the employees.

The processes of deindustrialization and restructuring of the economy result naturally in the sharp decline in industry employment. The drop in production is significant. The jobs and manufacturing in sectors for which our country is considered to have good potentials and traditions, as well as sectors in which it has invested a lot are being destroyed. The former includes light and food industries, and the latter - electronics, computing, 
electrotechnical industry, instrument-building, specialized equipment, etc. Thus, our country not only loses foreign markets and opportunities for accelerated growth and employment, incl. highly skilled labour, but also opportunities in the near future to change the technical and technological level of production, and for the country to retain and effectively use professionally trained and qualified professionals.

The expected institutional restructuring of scientific research - from institutions to universities, has not been carried out. Production is deprived of research and innovation needed to increase the efficiency and competitiveness of domestic production. The scientific potential reduced and scattered in many scientific fields is virtually ineffective also because of the limited funds that the budget can allocate for research and equipment.

The share of employees in the public and especially private sector receiving wages around the minimum wage is high. Part of private sector employees are still not insured for the social risks. This leads to an increase in the number and proportion of the so-called working poor, and increases insecurity and social differentiation. Some of them choose official unemployment to employment (benefits are relatively high or sufficient in size to be preferred to the receipt of income from work) or they continue to be unemployed to the alternative of low pay and uncertainty.

In the 1990s unemployment was high, widespread and continuous and led to profound social and economic changes in society. In reality, the labour supply was much greater because many school leavers or dropouts were not registered at labour offices, desperate and disillusioned unemployed left their official registration, pensioners and students also sought employment, etc. This labour supply was increased because a huge number of people were discharged from the army due to the ongoing reform in it. The unemployment rate in many communities during this period was over $30 \%$ and in some - over $40 \%$ and even $50 \%$. Most of these regions have mixed and compact Roma population. Only about 1/4 of the unemployed received benefits, or the majority of the unemployed had no income. Relatively few of them could hope for social benefits or involvement in subsidized employment programmes. The majority of the unemployed had low education, no professional training and/or no work experience. The majority of them were Roma, young people and women. About $60 \%$ of the unemployed had low education and without profession, which means that under favourable economic growth, increase in foreign investments, increased labour demand they are very unlikely to find paid employment. And this was confirmed in practice, when in the following years, the country registered high growth, high demand for labour and even nationwide shortage for labour. Unemployment, albeit significantly reduced, remains relatively high, especially for the unemployed of the so-called risk groups (long-term unemployed, low education, no profession, disabled, etc.). For many of them, the sphere of paid work became inaccessible and entering there was by chance, non-continuous, and uncertain. This, in turn, gave birth to social insecurity in society and in the 'best' case - employment in the informal economy, migration, etc.

The employment policy has long been focused mainly on the unemployed, to financing highly restricted activities, professional guidance and training, promoting and encouraging the unemployed to start work and employers to hire certain groups of unemployed. Still a very small portion of the funds is used for active policy, teaching, vocational training and retraining of unemployed, for job creation in the real economy for the long-term unemployed, to increase the mobility of the workforce and others, which would actually reduce unemployment and the social tensions that it raises.

Employment and unemployment are closely related and depend on the cycles and characteristics of economic development and its management. On the other hand, as a product of the functioning of the labour market, they need to be considered in the context of the general economic theory of market economy, highlighting the capacity and efficiency of public policy for intervention and regulation.

Despite the existing differences in the level and structure of employment, there are some general trends and structures such as:

- reducing significantly employment in primary sector industries, the extractive ones (agriculture, ore mining, coal mining), etc.;

- Reducing employment in secondary sector industries (processing industry, construction, etc.);

- Increasing employment in the tertiary sector (services);

- Increasing the educational level of employees, reducing the number of employees with lower than secondary education;

- Increasing women's employment; 
- Reducing the share of employees with a permanent contract and increasing the hiring for certain periods;

- Increasing the proportion of part-time and other non-traditional forms of employment;

- The majority of employees are hired, the proportion of employers and self- employed is below $1 / 5$ of the total employed.

The following factors or policies affect the level of employment and unemployment for their activation:

- A policy to increase employment of the population as part of the macroeconomic policy and as a policy to reduce imbalances in labour markets;

- The level of education and vocational training, the degree of compliance between the preparation of the economically active population and the demand by organizations;

- the policy for development and improvement of the preparation of population, the policy for investment in human capital;

- The level of economic development, the structure of the economy and the guidelines for its development;

- The policy for development of small and medium-sized enterprises to promote entrepreneurship and selfemployment;

- The development and improvement of laws and by-laws to ensure the right to work and to create opportunities for the realization of this right by the various population groups;

- The policy for development of the regions and populated localities with high unemployment and declining economy;

- The financial, tax and investment policies of the state, creating the environment for economic activity of enterprises so that their demand for labour increases;

- The social and demographic policy, the income and special protection policy for certain categories of the population in the sphere of employment, etc.

The strategic goal of the employment policy is to achieve full and productive employment of those who can and are willing to work. The objectives and specific tasks for the realization of this goal are related to the development of both the economy and the population to achieve a perfect match between supply and demand of labour, to create job opportunities for everyone, and for enterprises - to increase their competitiveness and efficiency.

In a market economy and labour market the scale and the level of employment and unemployment of the economically active population are determined by the labour market and by the market forces governing supply and demand for labour (Terziev, Kanev, 2019; Terziev, 2019a-k; Terziev, 2018-d; Terziev, Georgiev, 2018e-f; Terziev, Arabska, 2014; Terziev, 2015-b; Terziev, Arabska, 2016a).

\section{CONCLUSION}

Taking into account the development of the labour market, depending on the periods of economic development and the place and role of the labour mar-ket policy in the general economic policy in Bulgaria enables us to make several major conclusions for future development:

The sensitivity of the labour market and its main parameters will increase in the future and will experience both the positive and negative effects of the cy-clical economic development. The openness of the Bulgarian economy deter-mines the effects of external impacts and the ongoing reform processes in the country determine additional internal impacts on the labour market. Therefore, the efforts to increase the flexibility of the labour market through a relevant pol-icy should continue as they are an essential tool for softening the impacts and for timely adjustment. The more flexible the market is, the higher its adaptability will be to internal and external influences and the smaller the negative consequences will be.

The flexibility of the Bulgarian labour market is developed by diversifying the forms of the labour relations and the working time arrangements, by in-troducing new regulations on the labour relations, such as homebased work and remote working, by establishing a Temporary Employment Agency. Yet the tra-ditional models of labour relations and stereotypes of behaviour of employers and employees are still predominant.

The informal sector of the labour market complements the traditional pat-terns of labour relations by more flexible but illegitimate forms of employment and working time organization. The presence of this sector significantly deforms not only the image of the real employment in the country, but also the picture of its form 
and level of payment. Therefore, the policy for limiting this sector should remain one of the highlights not only of the labour market policy, but al-so of the economic policy in general.

A significant problem in the development of labour relations is the combi-nation of flexibility and security. So far, the flexibility of the Bulgarian labour market has been developing more actively than the security in labour relations in terms of employment contracts, wages and working conditions. In this sense, further development should be given to both the organization of the operation of labour inspectorates and its effectiveness, as well as to the actions for increasing the liability of employers, employees and the general public as a whole.

The underlying point in the evolution of labour market and employment in Bulgaria remains the formation of a coherent and sustainable strategy for eco-nomic development, with a clear vision for the structure of the economy and the demand for labour in the medium term. The deindustrialized Bulgarian economy determines the change in the structure of the labour demand in Bulgaria and the segmentation of employment. At the one pole stands the shrinking skilled work-force and at the other - the increasing mass unskilled labour. A similar structure of the workforce could hardly supply 'smart' economic growth and substantial growth of economic development in general. Bulgaria is experiencing serious difficulties in ensuring a quality workforce of specialists with secondary educa-tion, well-trained professionals with the necessary communication skills and ability to work with modern technologies. The outflow of 'middle class' special-ists from the country, in addition to the continuing emigration of young people, outlines not only quantitative but also qualitative problems with the workforce in the coming years. The stagnation in the economy, already continuing for several years, will come to an end in the coming years and then the revival of the labour demand will meet the limited supply of low-skilled labour. That is why at short notice our country must solve two very important issues that are outside the la-bour market, but affect it directly: first, how to stimulate the creation of jobs and second, in what sectors of the economy these jobs will be created - in sectors that provide high performance and competitiveness or in traditional and less productive sectors. The answer to these two questions will predetermine the fu-ture development in more distant horizons, it will provide a shift to a higher economic growth supported by productive and competitive work or development within the existing inefficient and technologically obsolete economic structures, seeking cheap workforce.

It is necessary to shift more to employment in the real economy at the ex-pense of employment growth in public administration and programmes for un-employed.

The main conclusion that can be made is that the implementation of special employment programmes is one of the alternative solutions for reducing the tensions in the labour market. Their implementation, together with local regional initiatives and programmes, has the potential to increase employment and reduce unemployment.

To sum up, the restructuring of the economy continues and the efforts should be directed at improving its efficiency and competitiveness, as well as at limiting the budget sector and especially the increase in its capacity. Employment policies can increase their capacities if they become long-term and more closely linked to national and regional economic development plans (Terziev, Arabska, 2014; Terziev, 2015-b; Terziev, Arabska, 2016a).

\section{REFERENCE LIST}

Georgiev, Marin. (2016). Obshtestvenoto i ikonomichesko razvitie v konteksta na sotsialnite politiki. // Spisanie za nauka „Novo znanie“. Visshe Uchilishte po Agrobiznes i Razvitie na Regionite, 5, 2016, N 4, str. 26-41, ISSN 2367-4598 (Online), (Print) ISSN 1314-5703 (Георгиев, Марин. Общественото и икономическо развитие в контекста на социалните политики. // Списание за наука „Ново знание“. Висше училище по агробизнес и развитие на регионите, 5, 2016, N 4, стр. 26-41, ISSN 2367-4598 (Online), (Print) ISSN 1314-5703.

Georgiev, Marin. (2017). Sbalansirovannaya karta kak alyternativa malogo biznesa. // Innovatsionnie tehnologii v nauke novogo vrmeni, Sbornik statey Mezhdunarodnoy nauchno - prakticheskoy konferentsii 1 fevralya 2017 g., Ufa NITS AETERNA, Chasty 1, 2017, s. 43-49, ISBN 978-5-00109004-5, ISBN 978-5-00109-007-6 (Георгиев, Марин. Сбалансированная карта как альтернатива малого бизнеса. // Инновационніе технологии в науке нового врмени, Сборник статей Международной научно - практической конференции 1 февраля 2017 г., Уфа НИЦ АЭТЕРНА, Часть 1, 2017, с. 43-49, ISBN 978-5-00109-004-5, ISBN 978-5-00109-007-6). 
Georgiev, Marin. (2017a). Impacts of active social programs on labor market. // Mezhdunarodnayy nauchnayy zhurnal „Innovatsionnaya nauka“. NITS Aeterna, N 02-1, 2017, pp. 139-143, ISSN 24106070 (Georgiev, Marin. Impacts of active social programs on labor market. // Международный научный журнал „Инновационная наука“. НИЦ Аэтерна, N 02-1, 2017, pp. 139-143, ISSN 24106070).

Terziev, V., Kanev, D. (2019). Modern developments in behavioral economics. // Smart Technologies and Innovations in Design for Control of Technological Processes and Objects: Economy and Production Proceeding of the International Science and Technology Conference „FarEastCon-2018” Volume 138, October 2-4, 2018, Vladivostok, Russian Federation, pp. 10-23, 2019, (Print) ISBN978-3-030-15576-6, (Online) ISBN978-3-030-15577-3.

Terziev, Venelin. (2019a). Provision of integrated employment and social assistance services in Bulgaria. // Smart Technologies and Innovations in Design for Control of Technological Processes and Objects: Economy and Production Proceeding of the International Science and Technology Conference „FarEastCon-2018” Volume 138, October 2-4, 2018, Vladivostok, Russian Federation, pp. 24-39, 2019, (Print) ISBN978-3-030-15576-6, (Online) ISBN978-3-030-15577-3.

Terziev, Venelin. (2019b). Problems of control in the social sphere. // INTCESS 2019- $6^{\text {th }}$ International Conference on Education and Social Sciences, 4-6 February, 2019, Dubai, International Organization Center of Academic Research, Istanbul, Turkey, pp. 577-593, ISBN: 978-605-82433-5-4.

Terziev, Venelin. (2019c). The criterion "competence" in the economic sector. // INTCESS 2019- $6^{\text {th }}$ International Conference on Education and Social Sciences, 4-6 February, 2019, Dubai, International Organization Center of Academic Research, Istanbul, Turkey, pp. 1241-1247, ISBN: 978-605-824335-4.

Terziev, Venelin. (2019d). Social policy and labor market development in Bulgarian transition period. // INTCESS 2019- $6^{\text {th }}$ International Conference on Education and Social Sciences, 4-6 February, 2019, Dubai, International Organization Center of Academic Research, Istanbul, Turkey, pp. 703-714, ISBN: 978-605-82433-5-4.

Terziev, Venelin. (2019e). Theoretical basis of development of labor market and social policy in the republic of Bulgaria. // INTCESS 2019- th $^{\text {th }}$ International Conference on Education and Social Sciences, 4-6 February, 2019, Dubai, International Organization Center of Academic Research, Istanbul, Turkey, pp. 715-726, ISBN: 978-605-82433-5-4.

Terziev, Venelin. (2019f). The problem of social efficiency- Indicators for social efficiency. // INTCESS 2019$6^{\text {th }}$ International Conference on Education and Social Sciences, 4-6 February, 2019, Dubai, International Organization Center of Academic Research, Istanbul, Turkey, pp. 669-678, ISBN: 978605-82433-5-4.

Terziev, Venelin. (2019g). Experiencing social policy development and efficiency measurment. // INTCESS 2019- $6^{\text {th }}$ International Conference on Education and Social Sciences, 4-6 February, 2019, Dubai, International Organization Center of Academic Research, Istanbul, Turkey, pp. 679-686, ISBN: 978605-82433-5-4.

Terziev, Venelin. (2019h). Efficiency and assessment of social technology. // INTCESS 2019- $6^{\text {th }}$ International Conference on Education and Social Sciences, 4-6 February, 2019, Dubai, International Organization Center of Academic Research, Istanbul, Turkey, pp. 687-694, ISBN: 978-605-82433-5-4.

Terziev, Venelin. (2019i). Conceptual framework of social adaptation. // INTCESS 2019- $6^{\text {th }}$ International Conference on Education and Social Sciences, 4-6 February, 2019, Dubai, International Organization Center of Academic Research, Istanbul, Turkey, pp. 494-503, ISBN: 978-605-82433-5-4.

Terziev, Venelin. (2019j). The dependence social adaptation- socialization. // INTCESS 2019- th $^{\text {th }}$ International Conference on Education and Social Sciences, 4-6 February, 2019, Dubai, International Organization Center of Academic Research, Istanbul, Turkey, pp. 478-485, ISBN: 978-605-82433-5-4.

Terziev, Venelin. (2019k). Social activity and human resources as social development factors. // INTCESS 2019- $6^{\text {th }}$ International Conference on Education and Social Sciences, 4-6 February, 2019, Dubai, International Organization Center of Academic Research, Istanbul, Turkey, pp. 546-553, ISBN: 978605-82433-5-4.

Terziev, Venelin. (2018). The active model of a social programme and its strategic advantage . // ADVED 2018- 4th International Conference on Advances in Education and Social Sciences Abstracts \& 
Proceedings, 15-17 October 2018- Istanbul, Turkey, International Organization Center of Academic Research, www.ocerints.org, Istanbul, Turkey, 2018, pp. 189-203, ISBN: 978-605-82433-4-7.

Terziev, Venelin. (2018a). Active social programs development in Bulgaria: contemporary challenges and social management instruments. // ADVED 2018- 4th International Conference on Advances in Education and Social Sciences Abstracts \& Proceedings, 15-17 October 2018- Istanbul, Turkey, International Organization Center of Academic Research, www.ocerints.org, Istanbul, Turkey, 2018, pp. 149-163, ISBN: 978-605-82433-4-7.

Terziev, Venelin. (2018b). Social assistance services and integrated employment in Bulgaria. // ADVED 2018- $4^{\text {th }}$ International Conference on Advances in Education and Social Sciences Abstracts \& Proceedings, 15-17 October 2018- Istanbul, Turkey, International Organization Center of Academic Research, www.ocerints.org, Istanbul, Turkey, 2018, pp. 164-177, ISBN: 978-605-82433-4-7.

Terziev, Venelin. (2018c). Impact of the labor market policies for ensuring employment. // ADVED 2018- $4^{\text {th }}$ International Conference on Advances in Education and Social Sciences Abstracts \& Proceedings, 1517 October 2018- Istanbul, Turkey, International Organization Center of Academic Research, www.ocerints.org, Istanbul, Turkey, 2018, pp. 178-188, ISBN: 978-605-82433-4-7.

Terziev, Venelin. (2018d). Importance of human resources to social development. // ADVED 2018- $4^{\text {th }}$ International Conference on Advances in Education and Social Sciences Abstracts \& Proceedings, 1517 October 2018- Istanbul, Turkey, International Organization Center of Academic Research, www.ocerints.org, Istanbul, Turkey, 2018, pp. 204-212, ISBN: 978-605-82433-4-7.

Terziev, V., Georgiev, M. (2018e). A strategic framework for the development of social entrepreneurship in Bulgaria. // Knowledge - International Journal, August 2018, Institute of Knowledge Management, Skopje, Macedonia, 25, 2018, N 1, pp. 23-34, ISSN 1857-923X (for e-version), ISSN 2545 - 4439 (for printed version).

Terziev, V., Georgiev, M. (2018f). Support for the development of social entrepreneurship in Bulgaria. // Knowledge - International Journal, September, 2018, Institute of Knowledge Management, Skopje, Macedonia, 26, 2018, N1, pp.57-74, ISSN 1857-923X (for e-version), ISSN 2545 - 4439 (for printed version).

Terziev, V., E., Arabska. (2014). Assessment of active social policies' impacts on labor market in the Republic of Bulgaria. Kolektivnaya monografiya "Sotsialyno-ekonomicheskie i pravovay razvitiya ekonomiki“, Ufa, Aeterna. Rossiya, 2014. ISBN 978-5-906769-97-8, str. 3-57 (Terziev, V., E. Arabska. (2014). Assessment of active social policies' impacts on labor market in the Republic of Bulgaria. Колективная монография „Социально-экономические и правовы развития экономики“, Уфа, Аэтерна. Россия, 2014. ISBN 978-5-906769-97-8, стр. 3-57).

Terziev, Venelin. (2015). Impact of active social policies and programs in the period of active economic transformations in Bulgaria, „East West” Association for Advanced Studies and Higher Education, Vienna, 2015, ISBN 78-3-903063-44-0, 434 p.

Terziev, Venelin. (2015a). Assessment of active social policies impact of social policies on transformation processes in bulgarian economy, Moscow, 2015, Publisher „Перо“, 110 p.

Terziev, Venelin. (2015b). Opportunities for improving the efficiency of the social adaptation of servicemen discharged from military service in Bulgaria:- Novosibirsk: Publisher CRNS, 2015. ISBN 978-5-00068402-3, $270 \mathrm{p}$.

Terziev, V., E., Arabska. (2016a). Effektivnoe vliyanie na raynok truda posredstvom uluchsheniya realizatsii sotsialynoy politiki. Novosibirsk: Izdatelystvo TSRNS, 2016. ISBN 978-5-00068-496-2, $312 \mathrm{str}$ (Терзиев, В., Е. Арабска. (2016а). Эфрфективное влияние на рынок труда посредством улучшения реализации социальной политики. Новосибирск: Издательство ЦРНС, 2016. ISBN 978-5-00068-496-2, 312 стр). 